\title{
Conditions for the effective development and protection of the resources of urban green infrastructure
}

\author{
Jacek Borowski ${ }^{1}$, Beata Fortuna-Antoszkiewicz ${ }^{2}$, Jan Lukaszkiewicz $^{2}$ *, Edyta Rosłon- \\ Szeryńska ${ }^{2}$ \\ ${ }^{1}$ Associated professor, Department of Environment Protection, Warsaw University of Life Sciences \\ - SGGW, ul. Nowoursynowska 159, bud. 37, Poland \\ ${ }^{2}$ assistant professors, landscape architects, Department of Landscape Architecture, Warsaw \\ University of Life Sciences - SGGW, ul. Nowoursynowska 159, bud. 37, Poland
}

\begin{abstract}
One of the basic conditions for the sustainable development of a modern city is the presence of a developed and efficiently functioning system of green infrastructure. It consists of all natural resources: greenery areas (gardens, parks, squares, street shelters, green roofs, etc.) and spontaneous (urban forests, green wastelands, etc.), water (watercourses and water reservoirs). Taking into account the specific, usually unfavorable conditions of the urban environment and the strong anthropopressure occurring there, all forms of vegetation should be subject to comprehensive management, including among others, the successful development of new facilities and plantings, as well as protection with the constant control and maintenance of existing valuable resources [2]. The long-term studies of the condition and transformations of urban tree stands $[1,3,4,5,6]$ conducted by the authors allow the formulation of a set of recommendations at the implementation level to ensure the efficient functioning of the green infrastructure in the city.
\end{abstract}

\section{Introduction - the importance, role and function of green infrastructure in cities}

Worldwide research on sustainable growth of modern cities show that it is dependent on, among others, introduction of an entirely separate type of urban infrastructure, which constitutes a fixed asset similar to technical infrastructure, the so-called grey infrastructure $[1,2]$. This idea is gaining in popularity as a concept of shaping green infrastructure. A green infrastructure system is an indispensable constituent of the urban system of a city, and includes open spaces and green areas located among city buildings. Green infrastructure is generally defined by identifying a range of criteria which determine its function [3], such as:

* corresponding author: jan_lukaszkiewicz@sggw.pl 
a) purpose: a system sustaining life in a given area, ensuring proper protection of natural aspects and of biodiversity, providing environmental, social and economical benefits, influencing city spatial composition etc.,

b) constituents: parks, open spaces, water reservoirs, scrubs, trees along streets, allotment gardens, villa districts, cemeteries, arable lands etc.

Shaping urban green infrastructure requires the simultaneous use of many criteria derived from various branches of scientific knowledge. For particular areas, those criteria may cause conflicts between functional, utilitarian and management concerns. This is also an essential and practical difficulty in implementing this concept. Selecting green infrastructure areas may be largely dependent on local hydrological conditions [3]. With land being covered to a large degree by vegetation and with a small amount of hard surfaces, hydrologically green infrastructure areas may behave similarly to country areas by ensuring surface water retention and facilitating the resupply of underground water reserves. Trees have a significant influence on the water balance of urban areas, especially those growing among densely distributed buildings in areas with non-permeable surfaces. Dense afforestation may strongly alter water distribution, favouring evapotranspiration. Research shows that trees growing in urban spaces offer a range of benefits for urban environment as well as urban dwellers. Apart from aesthetic value [4-8] and health benefits [7-9] natural benefits improvement of the urban environment $[7,8,10]$ - social $[7,10,11,12]$ and economic benefits $[13,14]$, all are considered extremely important. Long-term investment in trees in urban areas helps to reduce significantly higher costs generated by other sectors of the economy, such as the costs of erecting and maintaining "grey infrastructure" $[2,3,10,15]$. Trees, treated on par with technical infrastructure, require special attention in the city planning process $[2,16]$.

Considering specific and usually unfavourable urban conditions, and the strong anthropogenic pressure suffered by all forms of vegetation - especially trees - it has to be covered by a comprehensive management programme including, among others, the effective creation of new sites and plantings, as well as protection and constant monitoring and maintenance of existing valuable resources.

\section{Goal and methods}

Research carried out by the authors over many years on the condition and transformation of urban tree-stands allow formulating a set of practical recommendations for ensuring the effective functioning of urban green infrastructure. Various sites were researched (parks, squares, historical gardens, school gardens, vegetation along streets, in residential settlements, near water reservoirs, decoration of e.g. public utility buildings) as well as unmanaged green areas - mainly in Warsaw, but also in other Polish cities. The analysis included: historical transformation of vegetation spatial layouts (in particular sites and in the context of the entire city) [17-19]; urban tree-stand transformation dynamics [20-22]; means of using various tree species in different environmental conditions [23-29]; impact of technical infrastructure and modernisation works on tree condition [30-31]; health of older urban tree specimens, co called "veteran trees" [32]; planning the planting of vegetation [33, 34]. In particular, site level research was based on: an analysis of local conditions (natural, functional, spatial); vegetation inventories including, taxon identification and distribution, dendrometric measurements of selected specimens (in accordance with ISA and TROBI ${ }^{3}$ guidelines); phytosociological evaluations (using phytosociological photos and a 5-point Braun-Balnquet scale) to identify plant communities and forecast ecological stability of

\footnotetext{
${ }^{3}$ ISA - International Society of Arboriculture, Tree Ordinance Guidelines. TROBI - The Tree Register of the British Isles.
} 
identified phytocenoses. In order to gather more detailed data, additional analyses were carried out, including soil analysis (field and lab physicochemical analysis, analysis of reaction and firmness) as well as evaluation of condition of selected individual tree specimens, e.g. tree health - using the Dmuchowski and Badurek 2001 method [35]; tree vitality evaluation using the Roloff method 1989 [36]; biological function evaluation - using VTA (Visual Tree Assessment method) [37]; an evaluation of safety risk level and survival prognosis - WID method (Visual Identification of Trees constituting a safety hazard) [38]; a diagnosis of the condition of selected trees - study using an E-400 GMBH Labor resistograph.

\section{Results}

Based on the research and practical experiments, the authors have identified factors, which should be considered when planting new trees in an urban environment, as well as for the protection and maintenance measures of existing assets (especially in downtown area) which ensure the proper and effective functioning of urban green infrastructure.

\subsection{Soil modification}

One of the key aspects influencing the health and development of urban vegetation is habitat conditions. The modification of soil strata necessary for the proper growth of trees should be considered in the case of over compacted soil, improper chemical reaction, chemical pollution, and soil profile transformation. Conditions can be improved using inorganic materials or organic materials and biological methods. In especially difficult habitat conditions it is possible to use so-called soil compaction control methods [39].

\subsection{Possibility of increasing infiltration and retention of water in soil}

Retention level depends on soil type and structure. Proper cultivation and re-cultivation techniques may improve soil structure, especially in the case of firm and impermeable soils. Surface infiltration may be increased by, among others, interception of water by vegetation; replacement of impermeable surfaces by permeable ones; and using various engineering techniques [39].

\subsection{Effectiveness of vegetation in removing pollutants (phytoremediation)}

The ability of plants to absorb pollutants and thus clean air depends on their size - trees play the most significant part in this process. In terms of particulate matter reduction (plants absorb larger particulate matter $\left[\mathrm{PM}_{12}-\mathrm{PM}_{96}\right]$ better compared to smaller one $\left[\mathrm{PM}_{3}-\mathrm{PM}_{12}\right]$ ) coniferous trees and shrubs are more effective; while among deciduous trees more effective are those with rough leaves covered in hair. In terms of gas absorption (such as nitrogen oxides) and the absorption of volatile organic matter, trees with smooth leaves are more effective. Trees with a proper crown density ( $40 \%$ - loose crown structure) are most effective at cleaning air $[39,40]$.

\subsection{New plantings of trees - general information}

City management should be aimed at maximizing green areas. The location of new plantings depends on local requirements: local master plan, land ownership, type and location of buried utilities, spatial and compositional aspects. Diversified vegetation forms should be 
planned and adapted to environmental, technical and cultural requirements. When choosing an appropriate location for trees/shrubs it is important to consider the space available for the growth of crowns and roots (avoiding collisions with buildings and technical infrastructure; ensuring adequate space for development of root systems, especially for trees growing along roads). However, in locations where planting trees proves to be extremely difficult, other groups of plants (shrubs, vines, cover plants) planted in containers may be suitable [39].

\subsection{Selection of trees, shrubs and vines best suited to urban habitats}

The proper selection of trees, especially in unfavourable conditions for growth present in urban environment is crucial to successful cultivation [24, 41]. The species pool should be relatively large, to avoid creating monocultures. A plant's aesthetic qualities are of high importance. In parks, larger squares, and along less frequented roads, the pool of suitable species is a lot larger and it is possible to use plants which are more demanding in terms of habitat conditions. Plants planted in a difficult urban environment should be able to tolerate unfavourable habitat conditions. Despite the trend of using mainly native species, in most difficult habitat conditions one cannot exclude using alien species. When choosing the location and species of trees their phytoremediation qualities should be considered. In cities it is possible to use a variety of vines - which significantly increase green areas, especially in locations with a large number of buildings $[26,39]$.

\subsection{Existing plantings - guidelines for replenishing or replacement}

The replacement of trees and tree-stands is one of the maintenance measures for a green infrastructure system. Research carried out globally show that in the centre of large cities young trees can grow for no longer than 7-10 years since planting [35, 42, 43], which is why it is necessary to constantly replace dead tree specimens. These measures have to ensure the successive renewal of tree-stands, prolonging their existence and maintaining the mature tree-stand stage. Plantings have to be done methodically with regard to spatial aspects as well as functional and natural requirements of a given location [39].

\subsection{Supplementary plantings}

It is a form of environmental compensation related to administrative decisions allowing the removal of trees or shrubs used when it is impossible to relocate them [44]. Such activities are designed to ensure real compensation to the natural environment by planting new trees/shrubs which, as time goes by, will reach the desired natural quality [33, 39].

\subsection{Planting trees in various habitats}

Planting has to be preceded by the proper preparation of the site (achieving proper soil culture: ensuring right fertility and reaction for selected plants, correct grain-size). In extreme cases, shallow, polluted and over-compacted soil should be replaced. The effectiveness of new plantings in a city environment depends on the quality of the plant material (it should meet the quality criteria of the Polish Nurserymen Association and applicable local guidelines [39]). Plant parameters and planting techniques should be adapted to local conditions (such as: parks - street vegetation, city centre - periphery zones). Plants grown in Polish nurseries or colder climatic zones should be preferred. Planted trees need to be properly protected and maintained. It is advisable to leave an extensive area of uncovered soil around trees (min. 2.0-8.0 $\mathrm{m}^{2}$ per 1 tree) [43]. 


\subsection{Purposeful and successful tree relocation}

The relocation of healthy older trees/shrubs presenting a significant biological and aesthetic value is justified if they are threatened by, for example, new construction works. This is a highly invasive operation (significant reduction of the root system, lack of balance between the epigeal and underground part). When selecting specimens suitable for relocation it is necessary to consider their: health, aesthetic value, age, size, and total mass. Relocated plants require special maintenance measures [39].

\subsection{Regular maintenance}

City vegetation requires constant protection - without continuous, systemic maintenance vegetation is at risk of degradation, and individual sites (parks, street-side vegetation, etc.) may lose their form or value. Trees should be included in a comprehensive maintenance and protection programme (tree-stand management, site maintenance programmes). Protection should rely on preventive measures, which reduce the need for difficult and costly maintenance and prevent irreversible degradation (dying of plants, degradation of entire sites). In an urban environment (especially in city centre and along streets) it is necessary to ensure continuous maintenance for: young plantings, it includes mainly watering, weeding and mulching, and prevention of soil compaction; older trees require fertilization, soil aeration, reasonable and proper trimming (highly invasive measure), mechanical support of trees (both for tree protection and human safety). Street side plants require protection in winter (due to the use of $\mathrm{NaCl}$ in mixtures frequently used for defrosting in the direct proximity of trees/shrubs). The monitoring of tree and shrub conditions constitutes an important maintenance measure - it should include individual plants as well as habitat conditions $[29,39]$.

\subsection{Flower beds, lawns}

In green areas in cities, apart from trees, the surface forms of low vegetation play an important role. Flower beds - temporary elements but socially important as a decorative element in a public space. Lawns play an important part in the urban natural system (large area, strong impact). They can be divided into a few basic types based on the cost of its establishment, intensity and the cost of maintenance: carpet lawns (high maintenance and cost); park lawns (less intensive maintenance; species pool adapted to habitat conditions); meadow lawns (extensive maintenance; a valuable element enriching city ecological system); extensive lawns (formed as a result of vegetation succession; good resistance to unfavourable urban conditions); special lawns (sport, reinforced lawn surfaces; require the use of professional laying technologies and special maintenance) [39].

\section{Summary / conclusions}

Research and observations of urban green infrastructure carried out by the authors of this publication over many years allow making a summary and drawing conclusions. The undeniably correct functioning of a complex urban green infrastructure system depends on many things. Proper design and spatial planning, including green infrastructure aspects and giving it the proper attention are a necessary precondition. Without adapting and implementing a long-term strategy, green infrastructure cannot develop. Any corrective measures may only improve its current condition to a limited degree. Organisational measures are key. A very noteworthy example of a faulty administrative system is Warsaw, where green infrastructure management was divided between at least a few bodies. 
Consequentially, the comprehensive and uniform treatment of complex green infrastructure issues was impossible. The proper functioning of green infrastructure relies on the proper functioning of its constituent parts, especially plants - which should be located in suitable spots, properly selected, carefully planted, protected from unfavourable conditions and adequately maintained. The authors studied these latter aspects of green infrastructure in greatest detail, which allowed making the following conclusions:

1. The proper functioning of green infrastructure relies on ensuring a continuous urban green area system, which due to the complexity of urban anatomy is extremely difficult to achieve.

2. The entire system should be built around inter-connected, well designed, maintained and properly cared for parks, squares and residential district green areas.

3. The most important element binding scattered green enclaves is a properly maintained street network. It is extremely important to ensure that it is free of gaps and disruptions.

4. Maintaining the continuity of green infrastructure is particularly difficult in city centres characterised by the greatest changes to the natural environment. For this purpose, apart from new tree plantings, it is necessary to use all available plant types, including lawns, cover plants, flower beds, vines, green walls, and green roofs. Here, quality is as important as quantity.

5. Due to the amount of biomass they generate and their consequential impact on environment, trees are of principal importance to the functioning of a city's green infrastructure.

6. Large and old ("veteran") specimens have the greatest impact. One large urban tree often provides benefits equivalent to a few dozen young, new plantings. Their biocenotic and phytoremediatory influence is also hard to miss.

7. Study results and practical experience show that not all species grow well in difficult urban habitats, which is why proper species selection is very important.

8. Plants constituting an urban green infrastructure may be cultivated using, among others, modern technologies. Such solutions not only help to improve existing habitat conditions, but also allow the successful planting and maintaining of good condition of a whole spectrum of plant species, even in highly transformed and degraded areas.

9. When designing green infrastructure it is important to consider not only practical issues, but also local historical, urban, spatial and aesthetic circumstances.

All the above considerations regarding the functioning of a green infrastructure have to be implemented and included in applicable procedures, the most important of which the authors attempted to list in this article.

\section{References}

1. K. L. Wolf, in: C. Kollin (Ed.), Engineering Green: Proceedings of the 11th National Urban Forest Conference, Washington D. C.: American Forests (2003)

2. J. Schwab, in: American Forests, Spring 9-12 (2008)

3. B. Szulczewska (Ed.), Osiedle mieszkaniowe w strukturze przyrodniczej miasta (Wyd. SGGW, Warszawa, 2015)

4. A. Ptaszycka, Przestrzenie zielone w miastach (Ludowa Spółdzielnia Wydawnicza, Poznań, 1950)

5. W. Czarnecki, Planowanie miast i osiedli (PWN, Warszawa, 1970)

6. W. Niemirski (Ed.), Kształtowanie terenów zieleni (Arkady, Warszawa, 1973) 
7. M. Czerwieniec, J. Lewiñska, Zieleñ w mieœcie (IGPiM, Kraków, 1996)

8. M. Szumański, Strukturalizacja terenów zieleni (Wyd. SGGW, Warszawa, 2005)

9. R. S. Ulrich, R. F. Simons, B. D. Losito, E. Fiorito, M. A. Miles, M. Zelson, Journal of Environmental Psychology 11, 201-230 (1991)

10. E. G. McPherson, Arboriculture and Urban Forestry 33(1), 1-11 (2007)

11. E. Bartman, Wykorzystanie lasów do celów rekreacyjnych, in: Rozprawy naukowe, Zeszyty Naukowe A.R. w Warszawie, 33 (Zakªd Graficzny Politechniki Warszawskiej, Warszawa, 1974)

12. J. Formański, Psychologia środowiskowa (PZWL, Warszawa, 2004)

13. H. B. Szczepanowska, Synteza badań i założenia merytoryczne metody wyceny wartości drzew dla warunków polskich (IGPiM, Warszawa, 2009)

14. K. L. Wolf, Arboriculture \& Urban Forestry 35 (1), 33-40 (2009)

15. V. G. Mitchell, R. G. Mein, T. A. McMahon, Environmental Modelling and Software 16, 615-629 (2001)

16. C. C. Konijnendijk, R. M. Ricard, A. Kenney, T. B. Randrup, Urban Forestry \& Urban Greening 4, 93-103 (2006)

17. B. Fortuna-Antoszkiewicz, Przemiany formy elementów i układów ogrodowych wzdtuż traktów komunikacyjnych na przyktadzie Traktu Królewskiego w Warszawie (Wyd. Katedra Sztuki Krajobrazu SGGW, Warszawa, 2012)

18. B. Fortuna-Antoszkiewicz, J. Łukaszkiewicz, Czasopismo Techniczne 9/111, 127-136 (2012)

19. B. Fortuna-Antoszkiewicz, J. Łukaszkiewicz, P. Wiśniewski, Teka Komisji Urbanistyki i Architektury PAN, Oddział w Krakowie XLIV, 203-213 (2016)

20. J. Borowski, M. Pstrągowska, in: B. Szulczewska (Ed.) Osiedle mieszkaniowe w strukturze przyrodniczej miasta, Wyd. SGGW, Warszawa, 109-121 (2015)

21. B. Fortuna-Antoszkiewicz, J. Łukaszkiewicz, in: Biologia i ekologia roślin drzewiastych, Wyd. Bogucki Wyd. Naukowe, Poznań, 184-186 (2013)

22. B. Fortuna-Antoszkiewicz, J. Łukaszkiewicz, in: B. Świderek (Ed.) Special Element in its Surroundings - traces, Wyd. Oficyna Wydawnicza Wyższej Szkoły Ekologii i Zarządzania w Warszawie, Warszawa, 89-116 (2017)

23. J. Borowski, Wzrost rodzimych gatunków drzew przy ulicach Warszawy (Wyd. SGGW, Warszawa, 2008)

24. J. Borowski, in: 5 Wiosenna wystawa szkółkarska, Mazowiecka Zieleń 2012 - jakość i asortyment, Miasto w Zieleni - wyższa jakość życia, 4-12 (2012)

25. J. Borowski J., M. Pstrągowska, in: M. E. Drozdek, I. Wojewoda, A. Purcel (Eds.) Zieleń miast i wsi współczesna i zabytkowa, Techniki i technologie dla terenów zieleni, Oficyna Wyd. PSZ w Sulechowie, Sulechów, 7-18 (2009)

26. J. Borowski, P. Latocha, Rośliny pnace i okrywowe (Wyd. SGGW, Warszawa, 2014)

27. B. Fortuna-Antoszkiewicz, J. Łukaszkiewicz, in: J. Filipczak, B. Kowalska (Eds.) Zielone miasto - osobowość miejsca, Wyd. Agencja Promocji Zieleni Sp. z o.o., Warszawa, 5-18 (2013)

28. J. Łukaszkiewicz, B. Fortuna-Antoszkiewicz, Miškininkystė Ir Kraštotvarka [Forestry and Landscape Management], 1(12), 25-34 (2017)

29. E. Rosłon-Szeryńska, in: M. Kosmala (Ed.) Zieleń osiedlowa - stan obecny i wskazania do poprawy, Toruń, 195-206 (2010) 
30. B. Fortuna-Antoszkiewicz, J. Łukaszkiewicz, Rocznik Polskiego Towarzystwa Dendrologicznego Vol. 60, 77-83 (2012)

31. B. Fortuna-Antoszkiewicz, J. Łukaszkiewicz, in: J. Dolatowski (Ed.) Drzewa w cieniu człowieka, Warszawa, Wyd. Polskie Tow. Dendrologiczne, 34-35 (2014)

32. J. Borowski, E. Rosłon-Szeryńska (Eds.) Program objęcia specjalistycznymi zabiegami pielęgnacyjnymi wybranych starszych ,,drzew weteranów” $w$ Warszawie, Oprac. dla: Zarząd Zieleni m.st. Warszawy, Warszawa (2017) (to be published)

33. B. Fortuna-Antoszkiewicz, J. Łukaszkiewicz, in: Zielone miasto w procesie zmian, Wyd. Agencja Promocji Zieleni Sp. z o.o., Warszawa, 16-34 (2014)

34. B. Fortuna-Antoszkiewicz, J. Łukaszkiewicz, Nauka Przyroda Technologie 10, 4, \#50, 1-18 (2016)

35. W. Dmuchowski, M. Badurek, in: B. Gworek, A. Mocka (Eds.), Obieg Pierwiastków w Przyrodzie [Circulation of chemical elements in Nature] I, 218-224 (2001)

36. A. Roloff, Kronenentwicklung und Vitalitätsbeurteilung ausgewählter Baumarten der gemäßigten Breiten. Schriften aus der Forstlichen Fakultät der Universität Göttingen und der Niedersächsischen Forstlichen Versuchsanstalt (Sauerländer, Frankfurt am Main, 1989)

37. C. Mattheck, H. Breloer, Arboricultural Journal 18, 1-23 (1994)

38. E. Rosłon-Szeryńska, Uprawa i Ochrona drzew, Czasopismo Międzynarodowego Tow. Uprawy i Ochrony Drzew, Kluczbork, Nr 27, 89 (2012)

39. J. Borowski, B. Fortuna-Antoszkiewicz, J. Łukaszkiewicz (Eds.), Standardy ksztaltowania zieleni Warszawy, Zat. nr 7. do Programu Ochrony Środowiska na lata 2017-2020 z perspektywa do 2023 r. dla m.st. Warszawy, Uchwała Nr XXXVIII/973/2016 Rady m.st. Warszawy

(https://bip.warszawa.pl/NR/rdonlyres/0012d003/vxkmgrptdbnredpqifeqbborigwphleo /Za\%C5\%82acznik7doPo\%C5\%9BStandardy.pdf, Warszawa, 2016)

40. J. Borowski, in: Zielone Miasto - metamorfozy, 71- 82 (2011)

41. J. Borowski, P. Latocha, Rocznik Polskiego Towarzystwa Dendrologicznego Vol. 54, 83-93 (2006)

42. R. Foster, J. Blaine, Journal of Arboriculture 4, 14-17 (1978)

43. H. B. Szczepanowska, Drzewa w mieście (Hortpress, Warszawa, 2001)

44. Ustawa z dnia 16 kwietnia 2004 r. o ochronie przyrody z późniejszymi zmianami, Dz.U. z 2015 poz. 1651 (Environmental Protection Act Dz.U. of 2004, no. 92, item 880 as amended) 